\title{
Psychological Health of the Teaching Personnel of Physical and Sporting Education
}

\author{
Fairouz Azaiez ${ }^{1,2}$, Souhir Sbaa², Mouna Kecharem-Dammak ${ }^{2}$, Wafa Souissi' ${ }^{2}$, Meriam Zaibi ${ }^{2}$ \\ ${ }^{1}$ Higher Institute of Sport and the Physical Education of Sfax, Sfax, Tunisia \\ ${ }^{2}$ Studies Group of Development and Social Environment (Faculty of Letters and Social Sciences of Sfax), Sfax, \\ Tunisia \\ Email: fairouz.kyranis@yahoo.com
}

Received 2 February 2015; accepted 19 June 2015; published 23 June 2015

Copyright (C) 2015 by authors and Scientific Research Publishing Inc.

This work is licensed under the Creative Commons Attribution International License (CC BY). http://creativecommons.org/licenses/by/4.0/

(c) (i) Open Access

\section{Abstract}

Our objective is to identify the factors that are responsible for the health and the psychological distress of the teaching personnel. The problem of mental health of the teachers in general and the teachers of Physical and Sporting Education in particular remains a worrying situation for the researchers. The speed of the metamorphoses which took place in the world of education generates an intensification of the work of the teachers whose consequences assign the teaching personnel. This series of changes did not settle without effect. Already, $3.7 \%$ of the Tunisian teachers suffer from psychic disorders (Ghachem, 2012). This distress results in a high frequency of anxiety, professional irritation and exhaustion as well as a low level of vitality lived by the teachers. There are many studies which showed that the educational work is in crisis, searching for meaning, with teachers living a state of ill-being. As part of our research, we focus on the major determinants of psychological health and well being of teachers of physical education and sports in Tunisia. 151 teachers with mean age $(38.92 \pm 10.62)$ answered the questionary of Houlfort \& Sauvé $(2010)$. Our study showed serious negative effects on the mental health of Tunisian teachers due to several triggers of stress and tension at work. In addition, these health troubles due to different working conditions were variable depending on age, seniority, gender and also on marital status. Which are the factors responsible for the health and the psychological distress of the teachers of physical and sporting education?

\section{Keywords}

Health, Psychological Distress, Teachers, Physical and Sporting Education 


\section{Introduction}

The medium of education in Tunisia lived several changes since independence (1956): The budget of the ministry for national education is 3,507,335 million dinars Tunisian, that is to say 7.5\% of the GDP (2013). The education reforms were implemented following the holding of the top General of Education (reform 1955-1961; 1962-1969; 1970-1981; 1982-1986 and finally that of 1987-2006) (Chouk, 2012). The update of the Law on the state education which allots to the teachers a new role and new responsibilities which, moreover, technological missions and innovations (De Coninck et al., 2006). The challenges of the twenty-first century school are more demanding, more determined to democratize access to knowledge and finally articulate the personal and the universal (Meirieu, 2004). And finally, manpower of the increasingly many teachers and in growth (59,786 including 2774 teachers of Physical and Sporting Education in 2013 against 58,342 including 994 teachers of Physical and Sporting Education in 2005). Indeed, the Tunisian education system (Kaddour, 2009: p. 285) "is a partitioned system with increasing manpower and limited financial resources, a system with improved internal output and external poor yield, quality of transmission of know-how and very average innovation". The speed of the metamorphoses which take place in the world of education generates an intensification of the work of the teachers whose consequences assign the teaching personnel as much (psychological distress, exhaustion, irritation, anxiety and depression) (Hillock, 2005; Clot, 2008). This series of changes did not settle without effect. Already, 3.7\% of the Tunisian teachers suffer from psychic disorders (Ghachem, 2012).

The problem of mental health in the teachers in general and the teachers of Physical and Sporting Education in particular remain a worrying situation for the researchers like for the States. The demonstrations are varied, and the contexts are varied but the problem remains the same one (Geving, 2007; Chartrand, 2006; Janosz et al., 2004; Hakanen et al., 2006).

The management of the mental health then makes it possible to bring a new glance on the trade of teacher. The teachers seem to live more psychological disorders than the average of the workers in the public sector (Jolly, 2002; Priscilla, 2000; Kearns, 1986; Butt \& Lance, 2005).

The concept of psychological distress includes the negative symptoms inseparable psychological health of individuals (Ilfeld, 1976; Massé et al., 1998; Légaré et al., 2000). The most common manifestations are anxiety and depressive reactions towards life, fatigue, lack of energy, irritability, cognitive problems and withdrawal. Thus, the psychological distress does not constitute a specific mental disorder as well as the depression and professional exhaustion. However, it proves to be a significant estimated factor in the appearance of more severe mental disorders, such as the disorders of anxiety, the depression and the syndrome of stress post traumatic (Kessler et al., 2002; Poulin et al., 2010). Psychological health refers (Foucher \& Leduc, 2001; Foucher, 2004), on the one hand, with the possibilities that offer the organizational context, the working conditions and the capacity of the organization of the individual to even adjust itself to adapt (Kovess-Masféty et al., 2007); in addition, psychological health with work refers to the state that develops the individual compared to the indices which are the regard of oneself or the valorization of oneself, blooming, the balance of life and the level of stress (Klusmann et al., 2008; Gillespie et al., 2001; Hogan, Carlson, \& Dua, 2002; Leung, Siu, \& Spector, 2000; Winefield et al., 2001). On this subject, in a study carried out in Finland, the teachers showed a higher professional burn-up fraction than all the other workers of the public services (Hakanen et al., 2006). In addition, the sex, the age, the degree of schooling, the income, the number of years of seniority and the fact of having or not a spouse or children with his load are not characteristics associated with the psychological distress (Brun et al., 2003; Benach et al., 2002; Smith et al., 2000). What is against work of Bellerose et al. (1998), indeed, the level of schooling and the level of income are conversely associated with the psychological distress, the people being provided education for more and most educated being fewer to bring back a high level of distress as well as the index of psychological distress is more significant among women. In the same way, the studies of Chanlat (1986, 1985) and of Priscilla (2000) announce that the women as much as the men are immediately affected by the stress. It appears that the fact of having a harmonious passion for work that makes an individual able to feel a feeling of positive vitality with an absence of depression and anxiety (Vallerand \& Houlfort, 2003). What starts in the teacher a motivation towards his work. Thus, Deci et al. (1991) and Azaiez et al. (2013), regard the motivation as the whole of the conscious or unconscious factors which determines the behavior or the control of an individual to be acted of such or such way. These factors are characterized by a state of need responsible for release, maintenance and suspension of the behavior of the individual. According to Zacharyas (2010), the motivation in work is the first cause pushing the teacher with being always in form and forgetting tiredness and not 
to even smell the quantity of energy spent from where if there will be absence of motivation then systematically there will be a tiredness and especially a lower energy level (Fernet, Senécal, et al., 2008). The suffering of the teachers can be increased because they gradually lose the hope which their working conditions could improve (Dejours, 1990; Blaya, 2003). Consequently, they are afraid not to more find their vitality, because they lost confidence in them, in their own professional practice (Jeffrey \& Sun, 2008; Pollard, 2001).

On another side, Hammen \& Demayo (1982), studied the psychological distress and concentrated on a specific dimension of the distress which is the depression, the goal was to describe the symptoms of depression in the teachers, all that to include/understand at the end which the aspects psychological are associated the syndromes of depression. According to Fimian (1984) and Finlay-Jones (1986), excessive concern and the anxiety represent common demonstrations of stress. This anxiety then modifies appreciably the behavior of the person. Thus, Hiebert et al. (1984), observe that very anxious teachers spend less time working with pupils on behaviors directed towards the task and have tendency to less distributing positive reinforcers. Physical reactions can result in headaches, allergies, colds more frequent, hypertension and obesity. In a study undertaken by Fimian \& Santoro (1983), they identify six principal emotive demonstrations: frustration, the mental exasperation, an excessive concern, the feeling to be under pressure, depression and anxiety. Thus Feitler and Toklar (1981), indicate in a research which the teachers from 31 to 44 years would be stressed by their employment than those of less than 30 years or that those old of more than 45 years. In the same way as, the teachers having more than 10 years of experiment would also report a higher level of stress as those which have very few years of experiment. In another research, Schwab and Iwanicki (1982), report that the young teachers test more negative emotions compared to their work. The manifestations of the stress would also seem to vary according to whether the teachers work in primary schools or secondary (Feitler \&Toklar, 1981; Schwab \& Iwanicki, 1982). The problem of health and psychological stress do not result exclusively from factors connected to work as such, but also from the organizational and social context (participation in the decision-makings, relation with the parents, workload, the discipline and the management of class) (Bousnina-Bouallegue et al., 2003, 2005; Chanlat, 1985). Research shows that these sources of occupational stress can even have more impact that the factors connected to the task (Bourque et al., 1991; Friedman \& Greenhaus, 2000). In fact, an affectionate relation between the teacher and the pupil can support the social emotional and school development of the child (Decker et al., 2007; Rimm-Kaufman, 2011), while a high level of conflicts and dissensions between the teacher and the pupil come to whirl the teaching climate of the classes and the psychological health of the teachers (Baker, 2006; Fortin et al., 2004; Pianta \& Stuhlman, 2004). From where studies carried out by Genoud et al. (2007); Harvey (2002); Venet et al. (2009) and Martineau \& Corriveau (2000), confirm that the occupational stress and indiscipline (disturbing behaviors and heavy atmosphere) in class are a cause of the stress and professional exhaustion. As testifies it a Physical professor of Education "I do not support more the behavior of certain pupils: courtesy, problems of portable telephones etc I am irritated more quickly" (Dorvillé \& Camel, 2007). Many the teachers evoke however a change on the level of the behavior of the student. The students of today are: "impolite, less and less polished, disrespectful with their teachers", "they miss respect with the teachers, they are insolents, incorrect", "one hears vulgarities" (Bousnina-Bouallegue et al., 2003). However, another study undertaken in Greece by Avramidis \& Kalyva (2007), they concluded that the teachers of male sex who are exhausted express more negative attitudes towards the moved behaviors their pupils.

The precarious terms of employment are generally regarded also as vermin with the mental health (Pollard, 2001). Moreover, the risk of living distress increases significantly with the number of years of seniority (Smith et al., 2000). That can be astonishing at first sight, because the precarious terms of employment are generally regarded as vermin with the mental health (Brun et al., 2003; Maroy, 2006; Guibert et al., 2008).

However, it is interesting to announce that the studies of Janosz et al. (2004) and of Kovess-Masféty et al. (2007) showed that the quality of the relational climate with the direction and the colleagues can have a negative impact on the psychological health of the teachers. Moreover, of many studies stressed that the social support of the employees moderates association between the organizational factors of risk and their negative consequences on the individuals (Bliese \& Britt, 2001; Klusmann et al., 2008). In the same way, the great number of hours worked and the irregularity of the working hours are serious determinants of the psychological health of the teachers (Griva \& Joekes, 2003; Chartrand, 2006). The absence of consultation or participation (Chanlat, 1986) or the style of authority adopted (Chanlat, 1986) constitute a fundamental source of stress for the employees (Winefield \& Jarrett, 2001). With regard to the relational components with the parents, the quantitative indices of 
recognitions with regard to their work are significantly correlated with the psychological health of the teachers (Chartrand, 2006; Duchesne et al., 2005; Perreault, 2011).

\section{Method}

Our population of study is made up of 151 teachers of Physical and Sporting Education pertaining to various areas of Tunisia (Table 1). The average age is 38.92 with a Standard deviation of 10.62. The population of study is mainly male [102 teachers (average age 41.62 with a Standard deviation 10.11) and 49 teaching (average age 33.28 with a Standard deviation 9.44)]. Among participants 125 have a statute of regular employment (82.8\%) whereas 26 have a precarious statute of employment (17.2\%). It with is announced that the participations all in the study were of the volunteers, anonymities and confidential.

The data collected using the questionnaire included/understood scales of Likert (Houlfort \& Sauvé, 2010). This questionnaire evaluates nine dimensions, it was retained that four which identify the factors responsible for health and the distress psychology of the teaching personnel (Vitality experiment with work exhaustion health and greater comfort). The quantitative analysis thus includes/understands descriptive statistics, $X^{2}$ and variance analyses (ANOVA) carried out using the software "Statistical Package for the Social Sciences”. v.19.

\section{Results}

The variance analysis carried out on the symptoms of psychological distress of the teachers of physical and sporting education according to the kind (Figure 1) reveals a principal effect of safe group for the symptoms of depression (insulation, tears, discouragement and lack of interest) $(\mathrm{F}(1,149)=1.325$ with $p=252)$.

The results (Figure 1) indicate that the women live more of the symptoms of psychological distress than the men. Indeed, there is a significant interaction between professional exhaustion and the kind $(\mathrm{F}(1,149)=10.732$ with $p<.001$ ). This principal effect of the group is observable also between the anxiety (tension, fear), the symptoms cognitive (loss of memory) and irritability (anger, contrariety) and the kind (respectively $\mathrm{F}(1,149)=$ 9.823 with $p<002) ; \mathrm{F}(1,149)=6.268$ with $p<.01)$ and $\mathrm{F}(1,149)=5.268$ with $p<.02)$.

The variance analysis carried out on the factors of occupational stress of the teachers of physical and sporting education according to the kind (Figure 2) reveals a principal effect of group.

Among the factors of stresses included being studied (Figure 3), we note that the high workload is the principal one determining stress lived especially by the teachers women of Physical and Sporting Education (F (1, $149)=11.978$, significant difference with $p<.001$ ). The lack of time for the preparation of the courses, the colossal rate/rhythm of the days as well as the too high workload in general are elements which contribute to raise their level of stress to work. But aside the relational difficulties with the parents $(F(1,149)=4.456$ with $p<.05)$ and the management of the class $(\mathrm{F}(1,149)=8.226$ with $p<001)$, the women are more affected than the men by the relational difficulties lived with the colleagues $(\mathrm{F}(1,149)=3.920$ with $p<.05)$ and with the direction of the school establishments $(\mathrm{F}(1,149)=6.494$ with $p<.01)$. In exchange, the women reveal a higher score of satisfaction of their need for social affiliation $(\mathrm{F}(1,149)=5.954$ with $p<.01)$.

The variance analysis carried out on the factors of occupational stress of the teachers of physical and sporting education according to the age (Figure 3 ) reveals a principal effect of group on the level of the workload (F ( 3 , $147)=8.409$ to $p<.001)$, on the level of the difficulties relational with the colleagues (F $(3,147)=9.212$ with $p$ $<.001)$ and the parents $(\mathrm{F}(3,147)=6.155$ with $p<.001)$, with the satisfaction of the need for social affiliation $(\mathrm{F}(3,147)=8.049$ with $p<.001)$ and finally with satisfaction with the need for competence $(\mathrm{F}(3,147)=9.531$ with $p<.001$ ). The old teachers 30 years and less are touched by the high workload (average $=3.71$ ), followed by the old group between 31 and 40 years (average $=3.50$ ) (Figure 4 ). The two other groups differ significantly from the younger teachers (average $=3.46$ ), these groups paying to be affected by the load connected to their task.

\begin{tabular}{cccccccc}
\multicolumn{7}{l}{ Table 1. Population distribution by region. } \\
\hline & Sfax & Monastir & Tunis & Mahdia & Gabes & Sousse & Total \\
\hline Male & 34 & 6 & 5 & 50 & 4 & 3 & 102 \\
Female & 10 & 10 & 2 & 15 & 2 & 10 & 49 \\
Total & 44 & 16 & 7 & 65 & 6 & 13 & $\mathbf{1 5 1}$ \\
\hline
\end{tabular}




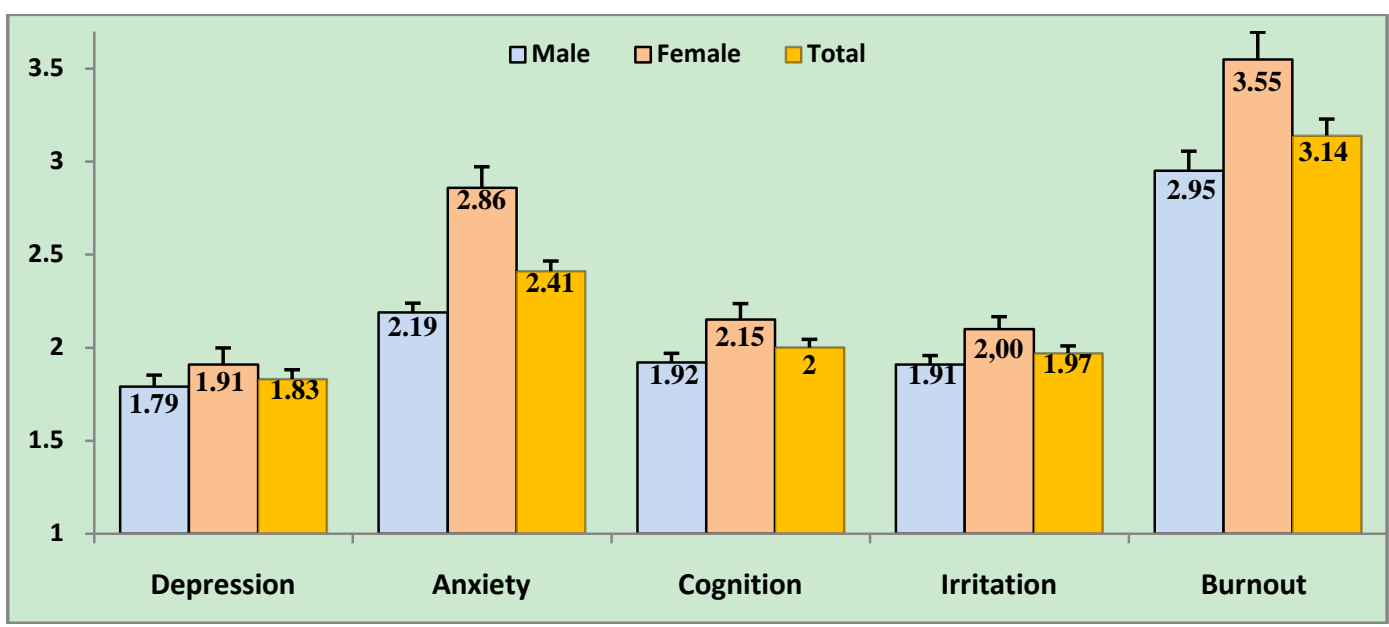

Figure 1. Scores of symptoms of psychological distress teachers by gender.

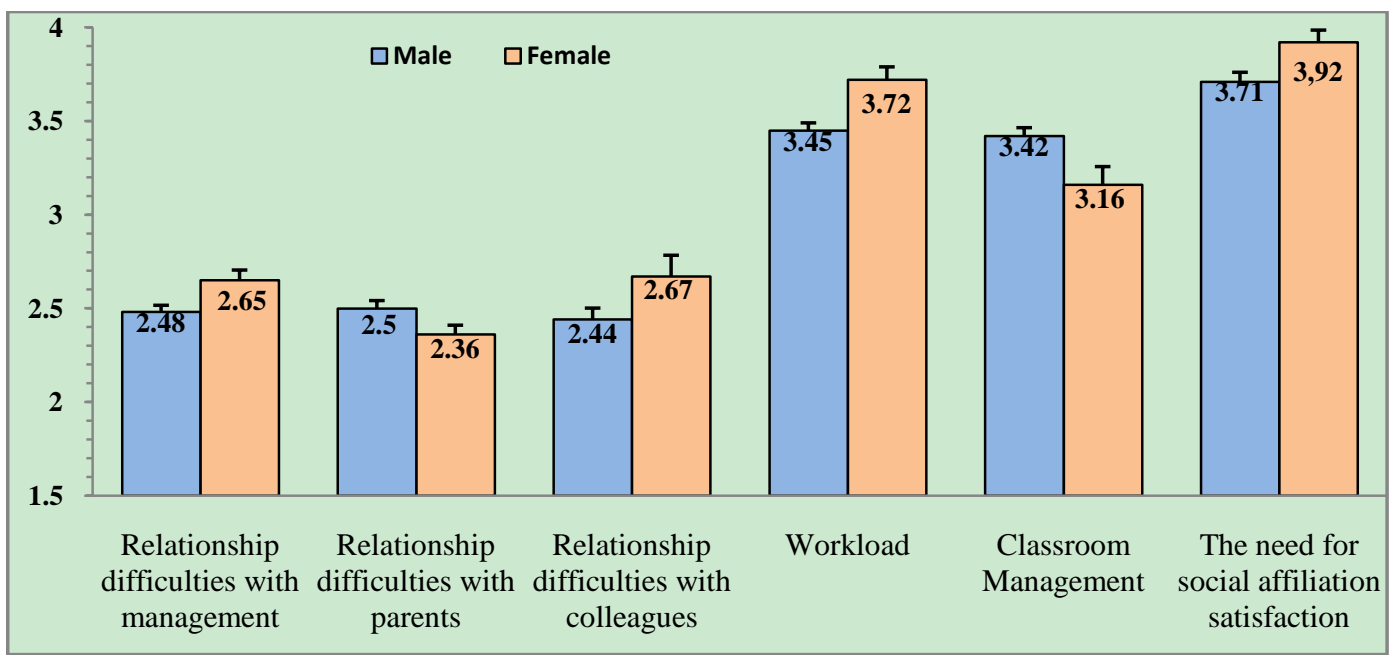

Figure 2. Degree to which occupational stress factors have an impact on teachers by gender.

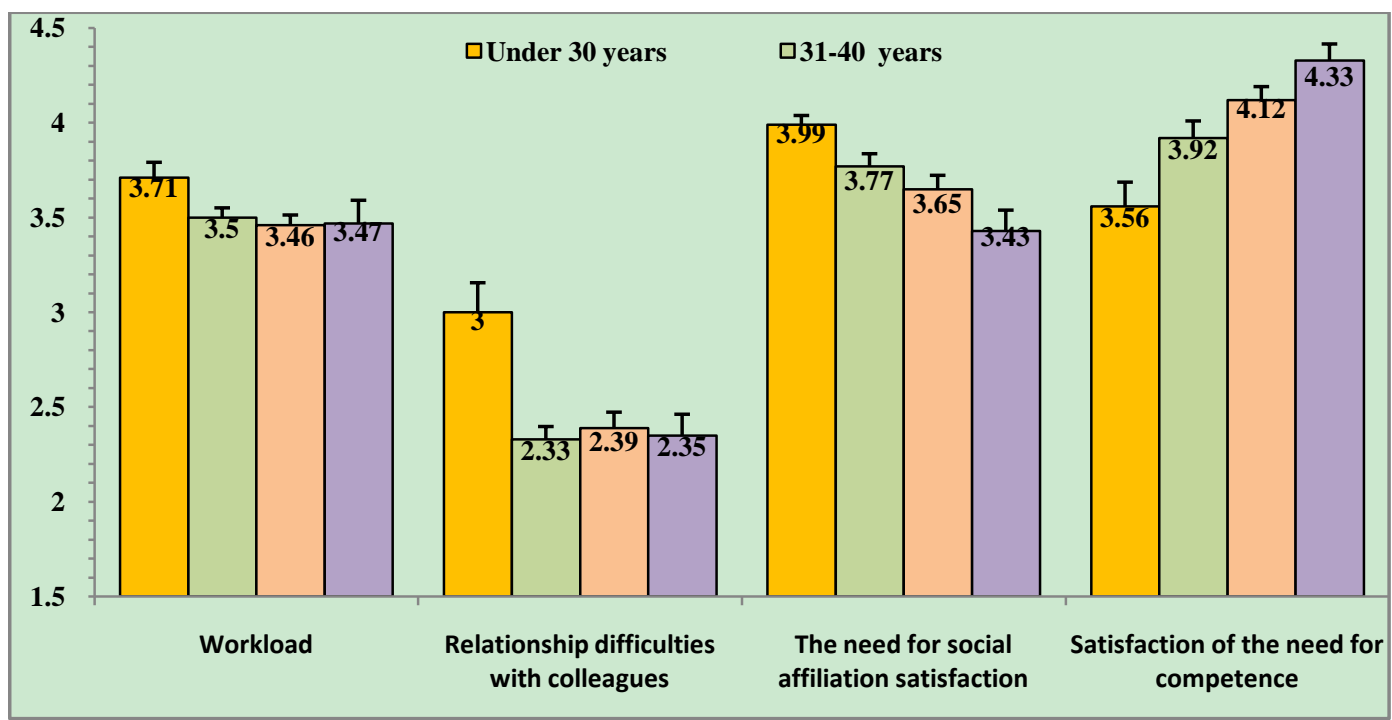

Figure 3. Degree to which occupational stress factors have an impact on teachers based age. 


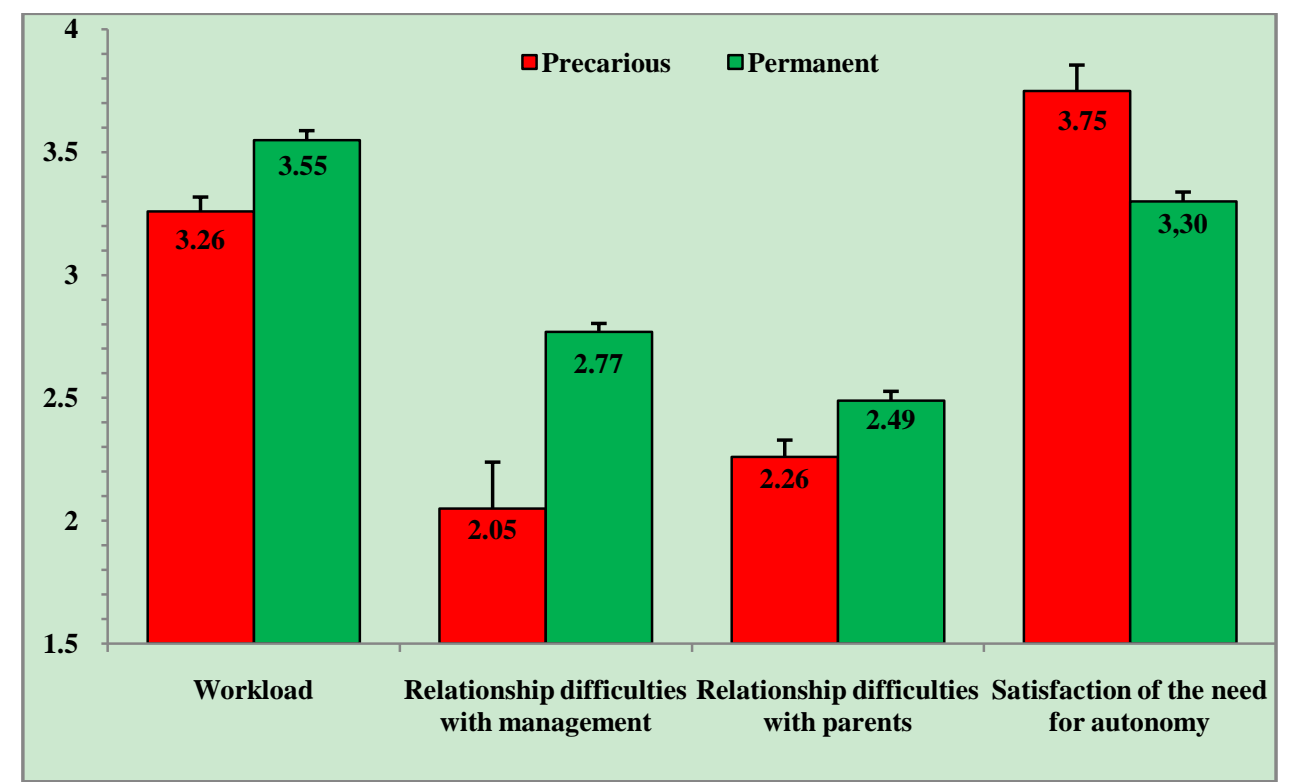

Figure 4. Degree to which occupational stress factors have an impact on teachers based on employment status.

The youngest teachers (30 years and less) bring back food less relational difficulties with their colleagues than the whole of the other teachers of EPS (average = 3), which explains finally why the satisfaction of their need for social affiliation is dominant (average $=3.99$ ). The teachers of old EPS more than 50 years feel more qualified than the other ages (average $=4.33$ ).

The results of this study also evoke that the precarious teachers are more sensitive to certain factors of occupational stress than the teachers of permanent Physical and Sporting Education (Figure 4). They are affected by the workload (average $=3.26$ vs 3.55 ) with an $\mathrm{F}(1,149)=10.750$ to $p<.001$. They also see that their need for autonomy to work is more satisfactory compared to that of the permanent teachers (average $=3.75$ vs 3.30 ) with an $\mathrm{F}(1,149)=22.045$ with $p<001$. Finally, the permanent teachers bring back food less relational difficulties with the parents and the direction that the precarious teachers (respectively, average $=2.28$ vs 2.08 and 2.31 vs 2.19 with an $\mathrm{F}(1,149)=6.852$ with $p<.01$ et an $\mathrm{F}(1,149)=40.477$ with $p<.001$ ) (Figure 4).

\section{Discussion}

Contrary to our beliefs and other studies carried out at the academics and professionals (Gillespie et al., 2001; Hogan, Carlson \& Dua, 2002; Leung, Siu, \& Spector, 2000; Winefield et al., 2001; Houlfort \& Sauvé, 2010) our conclusions evoke that the professors of Tunisian EPS do not dissociate general population on the level of psychological health and occupational stress.

The evaluation of the energy level of the teachers of Physical and Sporting Education, evoke that $45.10 \%$ never express or to seldom smell itself filled energy. These results are coherent with the studies of Houlfort \& Sauvé (2010). Nevertheless the variance analysis carried out reveals that there isn't significant difference between the level of vitality, the sex, the age and the statute of the teachers of Physical and Sporting Education. The lack of energy is not related to the characteristics of the professor (age, sex, and statute) but with the motivation towards its work (Azaiez et al., 2013). The motivated teacher is always forms and forgets of it tiredness (Fernet, Senécal, et al., 2008; Zacharyas, 2010). The suffering of teachers may be increased because they gradually lose the hope that their working conditions could be improved (Dejours, 2008; Blaya, 2003). Consequently, the professors are afraid not to more find their vitality, because they lost confidence in them, in their own professional practice (Jeffrey \& Sun, 2008). One finds a difference significant between the psychological distress and the sex (Brun, 2003; Benach et al., 2002; Smith et al., 2000). Thus the women have an index of psychological distress more significant than the men. That goes in the direction of the studies of Chanlat $(1985,1986)$ and Priscilla (2000).

With regard to the determinants of the psychological health of the teacher in relation to the sex, the statute and the age reveal a difference significant (Friedman \& Greenhaus, 2000). 
Indeed, the men live relational difficulties with the parents and the pupils. On the other hand the women are affected by the workload and have relational difficulties with the direction and the colleagues. And have a need for social affiliation higher than the men. These results are confirmed by work of Venet et al. (2009), Genoud et al. (2007), Papart (2003) and of Perreault (2011).

The precarious terms of employment are generally like vermin with the psychological health of the teacher. The quality of the relational climate can have a negative impact on the psychological health of the teachers. Studies of Pollard (2001), Kovess-Masféty et al. (2007) and those of Duchesne et al. (2005) our results confirm. However, the precarious teachers have a need for autonomy more satisfactory than the permanent ones which is with the adaptation more easily to the teaching revival (Houlfort \& Sauvé, 2010). Indeed, the precarious terms of employment are generally regarded as noxious with the mental health (Pollard, 2001). Moreover, the risk of living distress increases significantly with the number of years of seniority, the older employees being at the risk to more bring back a high level of distress compared to the least old. The whole of these results agrees with work of Winefield and Jarrett (2001).

Lastly, it is significant to stress that, in the majority of the studied organizations, the social support of the colleagues of work decreases the risk considerably to bring back a high level of distress. This relation is coherent with the results of other studies in work environment and in the general population (Légaré et al., 2000). Such as Theorell $(1997,2000)$ indicates it, the social support seems to play a role essential in the stress with work, since it protects the individual against the negative effects of an employment comprising from the excessive requirements.

\section{Conclusion}

The objective of this research was to identify the factors responsible for the health and the psychological distress of the teaching personnel of Physical and Sporting Education. A review of the literature made it possible to present a synthesis relating to the principal factors responsible for the degradation of the psychological health of the teachers of Physical and Sporting Education. To identify these factors, one used a questionnaire near 151 teachers of Sports and Physical Education to find the principal sources of health and psychological distress to knowing the symptoms of psychological distress (depression, anxiety, irritation and exhaustion) and the occupational stress (relation with the parents, pupils, colleagues and the load of work).

All things considered, the results of this study reveal us that almost half of the teachers live a fall of energy and that the women are affected by symptoms of psychological distress than the men. And finally, the permanent teachers bring back food less relational difficulties than the precarious ones.

The principal limit of this study lies in the sample which is not representative of the study population. In Tunisia, where the extent of the problems of psychological health is similar to that of Europe or of America like it Levi and Lunde-Jensen (1996) showed that the costs of psychological health are of the same amplitude than those of cancer or many industrial accidents. Consequently, the prevention of this distress (anxiety, of professional irritation and exhaustion as well as a low level of vitality lived by the teachers) must obviously appear among the prerogatives of the policies of the public health in Tunisia.

\section{References}

Avramidis, E., \& Kalyva, E. (2007). The Influence of Teaching Experience and Professional Development on Greek Teachers’ Attitudes towards Inclusion. European Journal of Special Needs Education, 22, 367-389. http://dx.doi.org/10.1080/08856250701649989

Azaiez, F., Chalghaf, N, Mesaoudi, H., Sbaa, S., \& Bahloul, M. (2013). The Work Motivation at The Tunisian Teachers of Physical and Sporting Education. International Journal of Humanities and Social Invention (IJHSS), 2, 42-49.

Baker, J. A. (2006). Contribution of Teacher-Child Relationships to Positive School Adjustment during Elementary School. Journal of School Psychology, 44, 211-229. http://dx.doi.org/10.1016/j.jsp.2006.02.002

Bellerose, C, Lavallée, C., Chénard, L., \& Levasseur, M. (1998). Et la santé, ça va en 1992-1993? Rapport de l'enquête sociale et de santé 1992-1993, vol. 1 (412 p). Montréal: Ministère de la Santé et des Services sociaux, Gouvernement du Québec.

Benach, J., Gimeno, D., \& Benavides, F. G. (2002). Types of Employment and Health in the European Union. European Foundation for the Improvement of Living and Working Conditions. Luxembourg: Office for Official Publications of the European Communities. 
Blaya, C. (2003). School Violence and the Professional Socialization of Teachers: The Lessons of Comparisons. Journal of Educational Administration, Amidale, 41, 650-668. http://dx.doi.org/10.1108/09578230310504643

Bliese, P. D., \& Britt, T. W. (2001). Social Support, Group Consensus, and Stressor-Strain Relationships: Social Context Matters. Journal of Organizational Behavior, 22, 425-436. http://dx.doi.org/10.1002/job.95

Bourque, J.-J., \& Charlebois, P. (1991). Gestionnaires: Résistez à la pression. Revue Internationale de Gestion, 15 , 25-30.

Bousnina-Bouallegue, Z., \& Hechiche-Salah, L. (2005). La gestion du stress, une nouvelle responsabilité sociale pour l'entreprise. Marrakech: 7e Université de Printemps de l'Audit Social—Performances Economiques \& Performances Sociales à l'heure de la R.S.E., 5, 6 et 7 mai 2005, Marrakech, Maroc.

Bousnina-Bouallegue, Z., Hechiche-Salah, L., \& Touzani, M. (2003). La gestion du stress des enseignants à l'université: Le cas de la Tunisie. Grenoble: Actes du XIVe Congrès de l'AGRH,.

Brun, J. P., Biron, C., \& Ivers, H. (2003). Évaluation de la santé mentale au travail: Une Analyse des Pratiques de Gestion des ressources humaines. Montréal: Institut de Recherche Robert Sauvé en Santé et en Sécurité du Travail.

Butt, G., \& Lance, A. (2005). Secondary Teacher Workload and Job Satisfaction, Do Successful Strategies for Change Exist? Educational Management, Administration and Leadership, 33, 401-422. http://dx.doi.org/10.1177/1741143205056304

Chanlat, J. F. (1985). Le stress et la santé des cadres de direction masculins: Mythe et réalités I. Le mythe du "prix du succès”. Revue Internationale de Gestion, 11, 5-14.

Chanlat, J. F. (1986). Le stress et la santé des cadres de direction masculins: II. Les réalités du stress professionnel. Revue Internationale de Gestion, 11, 44-49.

Chartrand, L. N. (2006). Métis Residential School Participation: A Literature Review. In L. N. Chartrand, T. E. Logan, \& J. D. Daniels (Ed.), Métis History and Experience and Residential Schools in Canada (pp. 5-55). Ottawa, ON: Aboriginal Healing Foundation.

Chouk, S. (2012). L'apprentissage demain savoirs et outils: Ébauche de réflexion prospective dans le contexte tunisien, Projet: Prospective pour la recherche, éducation et apprentissage à l'horizon 2030. Paris: ENS Cahan.

Clot, Y. (2008). Travail et pouvoir d'agir. Paris: Presses Universitaires de France.

De Coninck, F., \& Gollac, M. (2006). L’intensification du travail: De quoi parle-t-on? In P. Dans, D. Askenazy, \& F. D. Cartron (Eds.), Organisation et Intensité du Travail. Toulouse: Octares Éditions.

Deci, E. L., Vallerand, R. J., Pelletier, L. G., \& Ryan, R. M. (1991). Motivation and Education: The Self-Determination Perspective. Educational Psychologist, 26, 325-346. http://dx.doi.org/10.1080/00461520.1991.9653137

Decker, D. M., Dona, D. P., \& Christenson, S. L. (2007). Behaviorally At-Risk African American Students: The Importance of Student-Teacher Relationships for Student Outcomes. Journal of School Psychology, 45, 83-109. http://dx.doi.org/10.1016/j.jsp.2006.09.004

Dejours, C. (1990). Nouveau regard sur la souffrance humaine dans les organizations. In J.-F. Chanlat (Ed.), L’individu dans l'organisation: Les dimensions oubliées (pp. 687-708). Laval: Presses de l’Université Laval.

Dejours, C. (2008). Travail, usure mentale: Essai de psychopathologie du travail. Paris: Bayard Éditions.

Dorvillé, C., \& Camel, S. (2007). L'enseignant de l'EPS a-t-il le droit de vieillir? Revue EPS, No. 324, Mars-Avril, Paris: Editions EPS.

Duchesne, C., \& Savoie-Zajc, L. (2005). L’engagement professionnel d'enseignantes du primaire: Une démarche inductive de théorisation. Recherches Qualitatives, 25, 69-95.

Feitler, F. C., \& Toklar, E. B. (1981). Teacher Stress: Sources, Symptoms and Job Satisfaction., Los Angeles, CA: Présentation au congrès de 1981 de l'American Educational Research Association.

Fernet, C., Senécal, C., Guay, F., Marsh, H., \& Dowson, M. (2008). The Work Tasks Motivation Scale for Teachers (WTMST). Journal of Career Assessment, 16, 256-279. http://dx.doi.org/10.1177/1069072707305764

Fimian, M. J. (1984). The Development of an Instrument to Measure Occupational Stress in Teachers: The Teacher Stress Inventory. Journal of Occupational Psychology, 57, 277-293.

Fimian, M. J., \& Santoro, T. M. (1983). Sources and Manifestations of Occupational Stress as Reported by Full Time Special Education Teachers. Exceptional Children, 49, 540-543.

Finlay-Jones, R. (1986). Factors in the Teaching Environment Associated with Severe Psychological Distress among School Teachers. Australian \& New-Zealand Journal of Psychiatry, 20, 304-313. http://dx.doi.org/10.3109/00048678609158878

Fortin, L., Royer, E., Potvin, P., Marcotte, D., \& Yergeau, É. (2004). La prédiction du risque de décrochage scolaire au secondaire: Facteurs personnels, familiaux et scolaires. Revue Canadienne Dessciences du Comportement, 36, $219-231$.

Foucher, R. (2004). La santé psychologique au travail: Une responsabilité partagée. Psychologie Québec, 21, 36-38.

Foucher, R., \& Leduc, F. (2001). Domaines de pratique et compétences professionnelles des psychologues du travail et des organisations, éditions nouvelles, Broché. Paris. 
Friedman, S. D., \& Greenhaus, J. H. (2000). Allies or Enemies? What Happens When Business Professionals Confront Life Choices? New York, NY: Oxford University Press.

Genoud, P. A., Brodard, F., \& Reicherts, M. (2007). Facteurs de stress et burnout chez les enseignants de l'école primaire. Revue Européenne de Psychologie Appliquée, 59, 37-45. http://dx.doi.org/10.1016/j.erap.2007.03.001

Geving, A. M. (2007). Identifying the Types of Student and Teacher Behaviours Associated with Teacher Stress. Teaching and Teacher Education, 23, 624-640. http://dx.doi.org/10.1016/j.tate.2007.02.006

Ghachem, R. (2012). La révolution de la santé mentale. http://www.tuniscope.com/index.php/article/18432/business/conseils/traumatique011715\#

Gillespie, N. A., Walsh, M. J., Winefield, A. H., Stough, C. K., \& Dua, J. K. (2001). Occupational Stress within Australian Universities: Staff Perceptions of the Determinants, Consequences and Moderators of Work Stress. Work and Stress, 15, 53-72. http://dx.doi.org/10.1080/02678370117944

Griva, K., \& Joekes, K. (2003). The Teachers under Stress: Can We Predict Wellness on the Basis of Characteristics of the Teaching Job? Psychology and Health, 18, 457-471. http://dx.doi.org/10.1080/0887044031000147193

Guibert, P., Lazuech, G., \& Rimbert, F. (2008). Enseignants débutants, “faire ses classes”. L'insertion professionnelle des professeurs du second degré. Rennes: Presses universitaires de Rennes.

Hakanen, J. J., Bakker, A. B., \& Schaufeli, W. B. (2006). Burnout and Work Engagement among Teachers. Journal of School Psychology, 43, 495-513. http://dx.doi.org/10.1016/j.jsp.2005.11.001

Hammen, C., \& Demayo, R. (1982). Cognitive Correlates of Teacher Stress and Depressive Symptoms: Implications for Attributional Models of Depression. Journal of Abnormal Psychology, 91, 96-101. http://dx.doi.org/10.1037/0021-843X.91.2.96

Harvey, Y. (2002). Le problème du stress et sa gestion chez les enseignants à l'ordre primaire: Une exploration. L'Université du Québec à Chicoutimi, Informations, 418, 275-330. http://dx.doi.org/10.1522/14486924

Hillock, S. (2005). Radical Social Work. In F. Turner (Ed.), Canadian Encyclopedia of Social Work (pp. 316-317). Toronto: Wilfred Laurier Press, Published Books.

Hogan, J. M., Carlson, J. G., \& Dua, J. (2002) Stressors and Stress Reactions among University Personnel. International Journal of Stress Management, 9, 289-310. http://dx.doi.org/10.1023/A:1019982316327

Houlfort, N., \& Sauvé, F. (2010). Santé psychologique des enseignants de la fédération autonome de l'enseignement. Canada: Ecole National d'Administration Publique.

Ilfeld, F. W. (1976). Further Validation of a Psychiatric Symptom Index in a Normal Population. Psychological Reports, 39, 1215-1228. http://dx.doi.org/10.2466/pr0.1976.39.3f.1215

Janosz, M., Thiebaud, M., Bouthillier, C., \& Brunet, L. (2004). Perception du climat scolaire et épuisement professionnel chez les enseignants. 13ème Congrès de psychologie du travail et des organisations, Bologne: AIPTLF.

Jeffrey, D., \& Sun, F. (2008). Persévérance et santé chez les enseignants en insertion professionnelle. In L. Dans Portelance, J. Mukamurera, S. Martineau, \& C. Gervais (Eds.), L'insertion dans le milieu scolaire: Une phase cruciale du développement professionnel de l'enseignant. Québec: Presses de l’Université Laval.

Jolly, A. (2002). Stress et traumatisme: Approche psychologique de l'expérience d'enseignants victimes de violence. Thèse de doctorat en psychologie clinique, Ardenne: L’Université de Reims Champagne.

Kaddour, K. (2009). Tunisie 2050. Tunis: CPU.

Kearns, J. (1986). Stress at Work: The Challenge of Change. BUPA Series: The Management of Health: Stress and the City. London: BUPA.

Kessler, R. C., Andrews, G., Colpe, L. J., Hiripi, E., Mroczek, D. K., Normand, S. L. T., Walters, E. E., \& Zaslavsky, A. M. (2002). Short Screening Scales to Monitor Population Prevalences and Trends in Non-Specific Psychological Distress. Psychological Medicine, 32, 959-976. http://dx.doi.org/10.1017/S0033291702006074

Klusmann, U., Kunter, M., Trautwein, U., Lüdtke, O., \& Baumert, J. (2008). Engagement and Emotional Exhaustion in Teachers: Does the School Context Make a Difference? Applied Psychology: An International Review, 57, $127-151$. http://dx.doi.org/10.1111/j.1464-0597.2008.00358.x

Kovess-Masféty, V., Carmen, R.-S., \& Sevilla-Dedieu, C. (2007). Teachers’ Mental Health and Teaching Levels. Teaching and Teacher Education, 23, 1177-1192. http://dx.doi.org/10.1016/j.tate.2006.07.015

Légaré, G., Préville, M., Massé, R., Poulin, C., Boyer, R., \& St-Laurent, D. (2000). Santé mentale. In Enquête sociale et de santé 1998 (2nd ed.). Québec: Institut de la statistique du Québec.

Leung, T. W., Siu, O. L., \& Spector, P. E. (2000). Faculty Stressors, Job Satisfaction, and Psychological Distress among University Teachers in Hong Kong: The Role of Locus of Control. International Journal of Stress Management, 7, 121138. http://dx.doi.org/10.1023/A:1009584202196 
Levi, L., \& Lunde-Jensen, P. (1996). A Model for Assessing the Costs of Stressors at National Level. Socio-Economic Costs of Work Stress in Two EU Member States. Dublin: European Foundation for the Improvement of Living and Working Conditions.

Maroy, C. (2006). Les évolutions du travail enseignant en France et en Europe: facteurs de changement, incidences et résistances dans l'enseignement secondaire. Revue Française de Pédagogie, 155, 112-142. http://dx.doi.org/10.4000/rfp.273

Martineau, S., \& Corriveau, G. (2000). Vers une meilleure compréhension du sentiment d'incompétence pédagogique chez les enseignants en insertion professionnelle au secondaire. Formation et Profession, 6, 5-8.

Massé, R., Poulin, C., Lambert, J., \& Dassa, C. (1998). The Structure of Mental Health: Higher-Order Confirmatory Factor Analyses of Psychological Distress and Well-Being Measures. Social Indicators Research, 45, 475-504.

http://dx.doi.org/10.1023/A:1006992032387

Meirieu, Ph. (2004). Faire l'école, faire la classe. Paris: Éditions ESF.

Papart, J. P. (2003). La santé des enseignants et des éducateurs de l'enseignement primaire. Genève: Département de l'Action Sociale et de la Santé.

Perreault, M. (2011). Vérification des liens entre les stresseurs, le soutien social, la santé psychologique au travail et la qualité de la relation élève-enseignant. Thèse présentée à la Faculté des études supérieures et postdoctorales, Montréal: Faculté des Arts et des Sciences, Université de Montréal.

Pianta, R. C., \& Stuhlman, M. W. (2004). Teacher-Child Relationships and Children’s Success in the First Years of School. School Psychology Review, 33, 444-458.

Pollard, T. M. (2001). Changes in Mental Well-Being, Blood Pressure and Total Cholesterol Levels during Workplace Reorganization: The Impact of Uncertainty. Work and Stress, 15, 14-28. http://dx.doi.org/10.1080/02678370110064609

Poulin, F., Capuano, F., Brodeur, M., Giroux, J., Vitaro, F., \& Verlaan, P. (2010). Prévenir les difficultés à l'école primaire en maximisant les apprentissages scolaires et sociaux en début de scolarisation. www.cclcca.ca/pdfs/FundedResearch/201009Poulin CapuanoBrodeurGirouxFullReport.pdf

Priscilla, E. (2000). Stress and the Workload of Professional Women in Sweden. Ada: The Academy of Management Executive.

Rimm-Kaufman, S., \& Sandilos, L. (2011). Improving Students’ Relationships with Teachers to Provide Essential Supports for Learning. www.apa.org/education/k12/relationships.aspx\#

Schwab, R. L., \& Iwanicki, E. F. (1982). Who Are Burned out Teachers? Educational Research Quaterly, 7, 5-16.

Smith, A., Brice, C., Collins, A., Matthews, V., \& McNamara, R. (2000). Scale of Occupational Stress: A Further Analysis of the Impact of Demographic Factors and Type of Job. Contract Research Report No. 311/200, London: HSE Books.

Theorell, T. (1997). Fighting for and Losing for Gaining Control in Life. Acta Physiologica Scandinavica, 640, $107-111$.

Theorell, T. (2000). Effect of Charge in the Psychosocial Work Environment on Sickness Absence: A Seven Year Follow up on Initially Healthy Employees. Journal of Epidemiology \& Community Health, 54, 484-493. http://dx.doi.org/10.1136/jech.54.7.484

Vallerand, R. J., \& Houlfort, N. (2003). Passion at Work: Toward a New Conceptualization. In S. W. Gilliland, D. D. Steiner, \& D. P. Skarlicki (Eds.), Emerging Perspective on Values in Organizations (pp. 175-204). Charlotte: Information Age Publishing.

Venet, M., Schmidt, S., Paradis, A., \& Ducreux, E. (2009). La qualité de la relation entre l'enseignante et ses élèves: Une simple affaire de cœur? In S. Schmidt (Ed.), Intervention Différenciée au Primaire en Contexte d'intégration Scolaire: Regards Multiples (pp. 61-90). Québec: Presses de l’Université du Québec.

Winefield, A. H., \& Jarrett, R. J. (2001). Occupational Stress in University Staff. International Journal of Stress Management, 8, 285-298. http://dx.doi.org/10.1023/A:1017513615819

Zacharyas, C. (2010). La résilience sous l'angle de l'autodétermination pour une meilleure santé psychologique des enseignants: Déterminer des types de résilience. Mémoire présenté à la Faculté des études supérieures en vue de l’obtention du grade de Maitrise en psychologie, Montréal: Faculté des études supérieures, Université de Montréal. 